\title{
Preparation and electrochemical application of a new biosensor based on plant tissue/polypyrrole for determination of acetaminophen
}

\author{
GHOLAMHOSSEIN ROUNAGHI* and ROYA MOHAMMADZADEH KAKHKI \\ Department of Chemistry, Faculty of Sciences, Ferdowsi University of Mashhad, Mashhad, Iran \\ ${ }^{\dagger}$ Department of Chemistry, Faculty of Sciences, University of Zabol, Zabol, Iran
}

MS received 2 September 2011; revised 30 September 2011

\begin{abstract}
Banana tissue containing polyphenol oxidase was incorporated into polypyrrole matrix to make a biosensor for the analysis of acetaminophen (ACT). The electrocatalytic behaviour of oxidized acetaminophen was studied at the surface of the biosensor, using various electrochemical methods. The advantages of this biosensor for the determination of acetaminophen are excellent catalytic activity, good detection limit and high exchange current density. The electrochemical and structural properties of the electrode were assessed using cyclic voltammetry, differential voltammetry, chronoamperometric techniques. The analytical properties (sensitivity, $I_{\mathbf{p}}$ ) of this biosensor increased with plant tissue loading. Also this new biosensor was successfully applied for determination of acetaminophen in biologic samples.
\end{abstract}

Keywords. Acetaminophen; banana tissue; polypyrrole; voltammetry.

\section{Introduction}

Paracetamol (N-acetyl- $p$-aminophenol, acetaminophen) is a long-established and one of the most extensively employed 'over the counter' drugs in the world. The compound is effective in reducing fever associated with bacterial and viral infections (Fanjul-Bolado et al 2009). The ready availability of acetaminophen has resulted in increased use of the compound in suicide attempts (Xiong et al 2009). Consequently it is vital to develop a reliable and sensitive technique for the determination of acetaminophen in a variety of matrices.

Many assays have been described for acetaminophen determination including titrimetric (Kumar and Letha 1997), chromatography (Pérez and Bello 1999; Wang 1999; Speed et al 2001), fluorometry (Vilchez et al 1995), UV spectrophotometry (Dunkerley and Adams 1997; Rodenas et al 2000; Erk et al 2001), capillary electrophoresis (Yang et al 1999) and IR spectroscopy (Eustaquio et al 1999). However, the majority of these methods suffer from some disadvantages such as high costs, long analysis time and requirement for sample pretreatment, and in some cases low sensitivity and selectivity that makes them unsuitable for routine analysis. Therefore, development of a simple, inexpensive, sensitive and accurate analytical method for determination of acetaminophen is of great importance.

Conducting polymers have attracted much attention, because of their many applications in solar cells, light-weight batteries, electroanalytical applications, and chemical sensors and biosensors (Genies et al 1983; Ivaska 1991; Li 1997; Gerard et al 2002; Majidi et al 2006). In the past

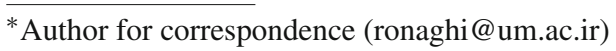

decade, an elegant strategy of biosensor construction based on the entrapment of biomolecules in polymer films during their electrogeneration on electrode surface was reported (Cosnier 1999). The electrically conducting polymers act as excellent materials for immobilization of biomolecules for the preparation of biosensors. Among the conducting polymers, polypyrrole and its derivatives play an important role due to their versatile applicability. Conducting polymers are used to enhance speed, sensitivity and versatility of biosensors to measure different analytes. They are also known to be compatible with the biological molecules in neutral aqueous solutions.

Plant tissue containing enzymes and plant-based biosensors offer a good alternative compared with biosensors based on isolated enzymes. These biosensors have some advantages, such as low cost, simplicity of construction, no need for a co-factor for enzyme regeneration, biocatalytic activity and improved stability (Wang and Lin 1988). In recent years plant tissue biosensors based on materials such as banana (Wang and Lin 1988), potato (Botre et al 1991), spinach (Oungpipat and Alexander 1994), mushroom (Akyilmaz and Dinckaya 2000), coconut (Lima et al 1997), palm tree (Felix et al 2006) and asparagus (Liawruangrath et al 2001) have been reported.

Several methods for the immobilization of biomolecules into the polymer matrix have been successfully applied. Tian et al (2001) developed a novel amperometric glucose biosensor by an electrochemical formation of polypyrrole membrane in the presence of glucose oxidase on the ceramic carbon electrode. Over-oxidation polypyrrole poly (O-phenylenediamine) bilayer biosensors have been developed with the enzymes glucose oxidase or cholesterol 
oxidase entrapped within an inner polypyrrole (PPy) layer (Vidal et al 1999). But the limited stability of isolated enzymes and the fact that some enzymes are expensive or even unavailable in the pure state. Therefore, in this work, we propose for the first time a novel system for construction of the PPy-modified biosensor based on the electrodeposition of polypyrrole on the plant tissue in a graphite based electrode. It describes a bioelectrochemical system for the determination of acetaminophen.

\section{Reagents and solutions}

Acetaminophen was obtained from Fluka. Pyrrole (analytical grade) was purchased from Merck. Sodium hydroxide and sodium dihydrogen phosphate were acquired from BDH. All aqueous solutions were freshly prepared by dissolving the solid salt in phosphate buffer solution at $\mathrm{pH} 7 \cdot 0$, as required. All aqueous solutions used in these experiments were prepared using doubly distilled water. All experiments were performed at a temperature of $25 \pm 1{ }^{\circ} \mathrm{C}$. The fresh banana used in the biosensor construction was purchased from the local market.

\subsection{Fabrication of enzyme electrode}

A graphite electrode was used as working electrode. While a platinum wire and an $\mathrm{Ag} / \mathrm{AgCl}$ electrode were used as counter and reference electrodes, respectively. The acetaminophen biosensor was fabricated by electropolymerization of pyrrole in a $50 \mathrm{~mL} 0 \cdot 2 \mathrm{M}$ pyrrole, $0 \cdot 1 \mathrm{M} \mathrm{LiNO}_{3}$. Polypyrrole formed electrochemically on the bioelectrode by the cyclic voltammetry method. In this procedure, the potential was scanned from -0.7 to $1.3 \mathrm{~V}$ at a scan rate of $50 \mathrm{mVs}^{-1}$ for seven times.

In order to construct PPy/banana tissue biosensor, a thin layer of fresh banana pulp was obtained by cutting with a spatula and formed on the base electrode. After that in the

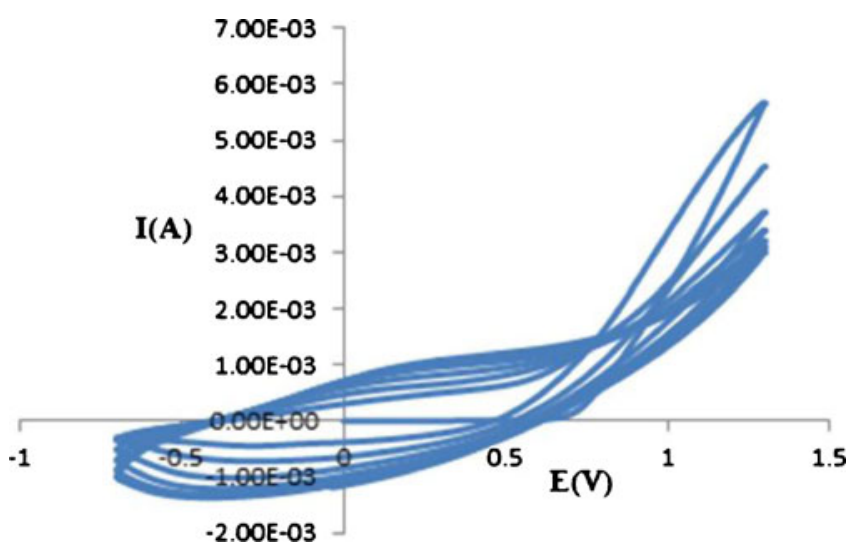

Figure 1. Repetitive CVs for polymerization process of PPy on base graphite electrode in $0 \cdot 1 \mathrm{M} \mathrm{LiNO}_{3}$ and a scan rate of $50 \mathrm{mVs}^{-1}$.

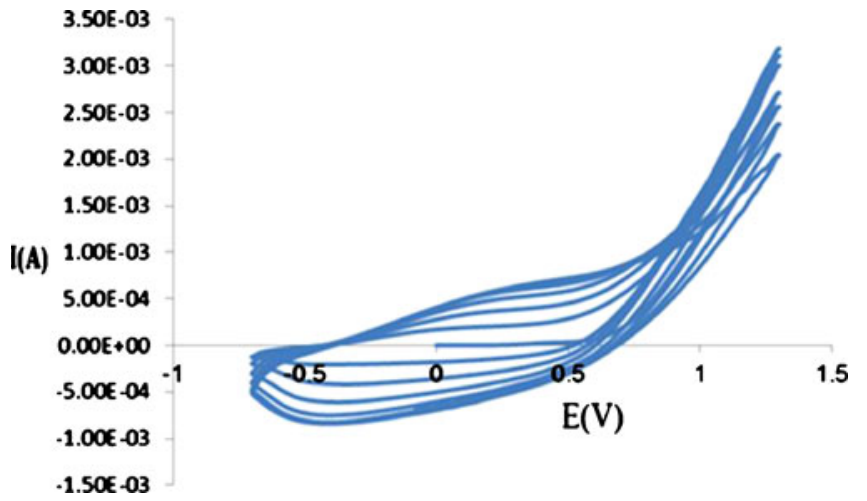

Figure 2. Repetitive CVs for polymerization process of PPy on banana/graphite electrode in $0.1 \mathrm{M} \mathrm{LiNO}_{3}$ and a scan rate of $50 \mathrm{mVs}^{-1}$.

same procedure as we maintained above, the electropolymerization of pyrrole was carried out. In this way, banana tissue strongly attached to the electrode surface. The electrode was washed and rinsed in double-distilled water to remove the unfixed tissues and then was used for the determination of acetaminophen.

Figures 1 and 2 show the cyclic voltammograms recorded during the electrochemical polymerization of pyrrole in the graphite electrode and graphite/banana electrode, respectively. In this method, electrochemical polymerization of pyrrole took place. Therefore, the PPy layer was found to be growing on the electrode surface. During the very first scan, we observed that the current started increasing at ca. $+1.15 \mathrm{~V}$, indicating the beginning of deposition process of PPy onto the electrode surface.

\subsection{General procedure}

A $50 \mathrm{ml}$ of acetaminophen standard solution $\left(10^{-5} \mathrm{M}\right)$ in $0 \cdot 10 \mathrm{~mol} \mathrm{~L}^{-1}$ phosphate buffer at $\mathrm{pH} 7$ was pipetted into the voltammetric cell. The cyclic voltammograms were obtained by scanning the potentials from -1.3 to $+1.3 \mathrm{~V}$ vs $\mathrm{Ag} / \mathrm{AgCl}$ electrode at a scan rate of $50 \mathrm{mVs}^{-1}$. The standard addition method was used to evaluate the content of acetaminophen in pharmacology samples by differential pulse voltammetry.

For the standard addition method, $50 \mathrm{ml}$ of unknown sample solution in phosphate buffer $\left(0.1 \mathrm{~mol} \mathrm{~L}^{-1}, \mathrm{pH} 7 \cdot 0\right)$ was pipetted into the voltammetric cell. Five voltammograms were recorded after step addition of $0.05 \mathrm{ml}$ of acetaminophen $(0.2 \mathrm{M})$ standard solution under the same conditions as above.

\section{Results and discussion}

After deposition of the doped polymer film, modified electrode was characterized in aqueous solution by using cyclic voltammetry and differential pulse voltammetry in an aqueous solution of $\mathrm{pH} 7$. 


\subsection{Electrocatalytic oxidation of acetaminophen on graphite modified electrode}

In this work, the electrochemical determination of acetaminophen at the graphite electrode modified with polypyrrole doped with banana tissue is reported. The cyclic voltammograms (CVs) were recorded at the bare graphite and PPy/graphite and PPy/banana tissue electrodes in the presence of acetaminophen and are shown in figures 3-5, respectively.

As can be seen from figure 3, a reversible pair of symmetrical redox peaks appeared at 0.393 and $0.395 \mathrm{~V}$ for the bare electrode. This obviously resulted from the oxidation and reduction of acetaminophen, since the electrode did not exhibit any current peak over this potential range in blank solution. From figure 5 it is clear that the oxidation peak is much more sensitive than the reduction peak. Therefore, oxidation peak was selected as the response signal for the determination of acetaminophen in this work. As can be seen from table $1, I_{\mathrm{pa}}$ in the bare electrode is about $1.75 \times 10^{-5} \mathrm{~A}$.

Polypyrrole (PPy) has a catalytic activity (Ramanavicius et al 2004; Raoof et al 2004; Khomenko et al 2005). As can be seen from figure 4, the PPy/modified carbon electrode gives increased oxidation signal to acetaminophen at a less positive potential $(0.407 \mathrm{~V})$ in contrast to that at the bare unmodified electrode $(0.423 \mathrm{~V})$.

At the PPy/banana tissue modified electrode a welldefined and sharp catalytic current $\left(3.8 \times 10^{-4} \mathrm{~A}\right)$ is observed in anodic scan and the corresponding cathodic current disappeared (figure 5). A catalytic effect was also observed and the oxidation peak shifts to $0 \cdot 01 \mathrm{~V}$ compared to unmodified $(0.407 \mathrm{~V})$ and PPy/modified $(0.423 \mathrm{~V})$ electrodes (table 1$)$. The performance of the signal is attributed to the presence of the enzyme polyphenol oxidase. The enzyme polyphenol oxidase, present in the banana tissue, catalyses the oxidation of acetaminophen. The oxidation current of acetaminophen at the modified electrode was more than 20 times to that of those observed at the bare graphite electrode. These results

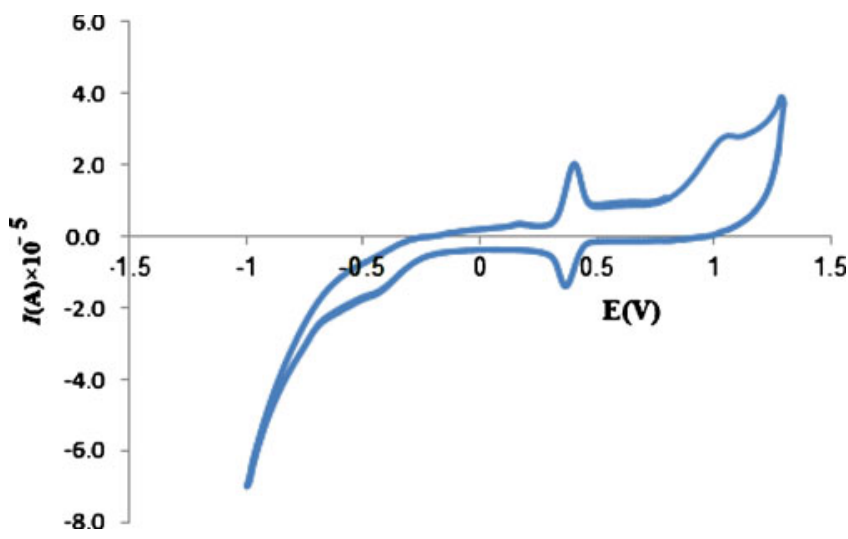

Figure 3. Cyclic voltammogram obtained by unmodified graphite electrode for $10^{-5} \mathrm{M}$ acetaminophen in phosphate buffer at $50 \mathrm{mV} / \mathrm{s}$.

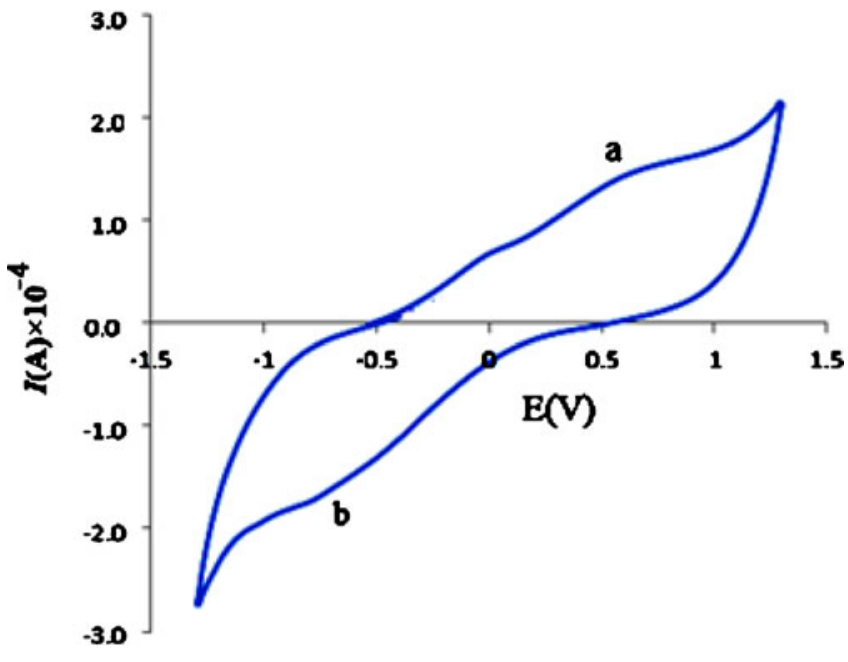

Figure 4. Cyclic voltammogram obtained by PPy/graphite electrode for $10^{-5} \mathrm{M}$ acetaminophen in phosphate buffer at $50 \mathrm{mV} / \mathrm{s}$.

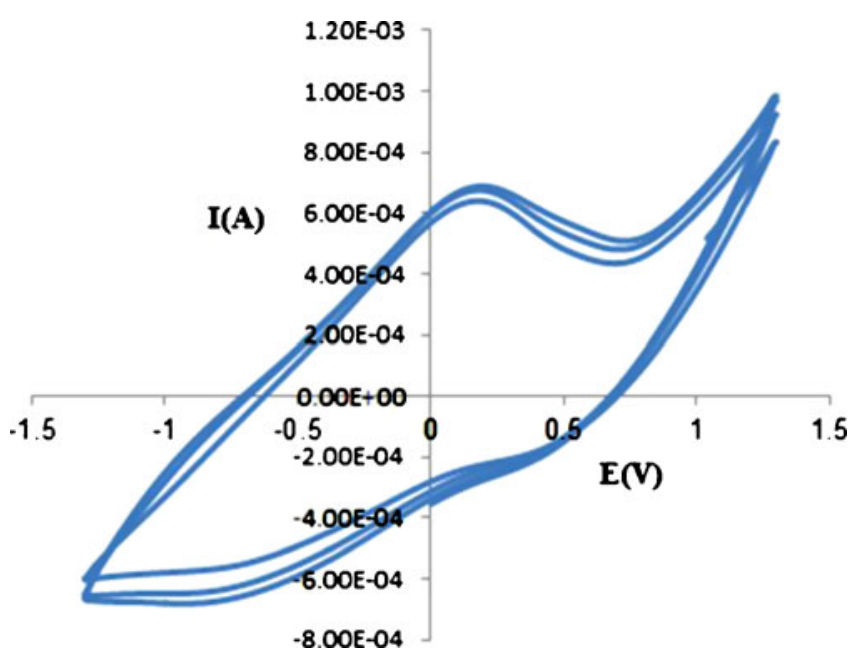

Figure 5. Cyclic voltammogram obtained by PPy/banana tissue graphite electrode for $10^{-5} \mathrm{M}$ acetaminophen in phosphate buffer at $50 \mathrm{mV} / \mathrm{s}$.

indicated that PPy/banana tissue electrode could accelerate the rate of electrochemical determination of acetaminophen.

\subsection{Chronoamperometric experiments}

The electrocatalytic oxidation of ACT at PPy/banana tissue modified electrode was investigated by chronoamperometric technique in order to evaluate the diffusion coefficient for the catalytic reaction of ACT in phosphate buffer $(\mathrm{pH} 7)$. The oxidative and reductive chronoamperograms were obtained. The forward and backward chronoamperograms obtained at the modified electrode appeared very symmetrical (figure 6). This was used to make the experimental plots of $I$ vs $t^{-1 / 2}$ (figure 7). For an electroactive substrate with diffusion co- 
efficient $D$, the current corresponding to the electrochemical reaction (under diffusion control) is described by Cottrell's law (Bard and Faulkner 1980):

$$
I=n F A D^{1 / 2} C / \pi^{1 / 2} t^{1 / 2}
$$

where $D$ and $C$ are the diffusion coefficient $\left(\mathrm{cm}^{2} \mathrm{~s}^{-1}\right)$ and bulk concentration (mol.cm ${ }^{-3}$ ), and $n, F$ and $A$ are electron number, Faraday number, and electrode area, respectively. The plot of $I$ vs $t^{-1 / 2}$ constructed from the Cottrell equation is linear, and from the slope, the value of $D$ can be obtained. An average diffusion coefficient of $8.31 \times 10^{-6} \mathrm{~cm}^{2} \mathrm{~s}^{-1}$ was calculated for acetaminophen.

\section{3 pH influence on biosensor response}

The $\mathrm{pH}$ influence was investigated at different $\mathrm{pH}$ values between 3 and 8 . Figure 8 shows the change of anodic pick current with $\mathrm{pH}$ for $1 \cdot 0 \times 10^{-5} \mathrm{~mol} \mathrm{~L}^{-1}$ acetaminophen in $0.1 \mathrm{~mol} \mathrm{~L}^{-1}$ phosphate buffer solutions. The maximum

Table 1. Electrochemical characteristics of acetaminophen in unmodified and modified electrodes.

\begin{tabular}{lccc}
\hline Parameters & $\begin{array}{c}\text { Graphite } \\
\text { electrode }\end{array}$ & $\begin{array}{c}\text { PPy/graphite } \\
\text { electrode }\end{array}$ & $\begin{array}{c}\text { PPy/banana graphite } \\
\text { electrode }\end{array}$ \\
\hline$I_{\mathrm{pc}}(\mathrm{A})$ & $1.02 \times 10^{-5}$ & $1.8 \times 10^{-5}$ & - \\
$I_{\mathrm{pa}}(\mathrm{A})$ & $1.75 \times 10^{-5}$ & $1.92 \times 10^{-5}$ & $3.8 \times 10^{-4}$ \\
$E_{\mathrm{pc}}(\mathrm{V})$ & 0.395 & -0.533 & - \\
$E_{\mathrm{pa}}(\mathrm{V})$ & 0.423 & 0.407 & 0.01 \\
\hline
\end{tabular}

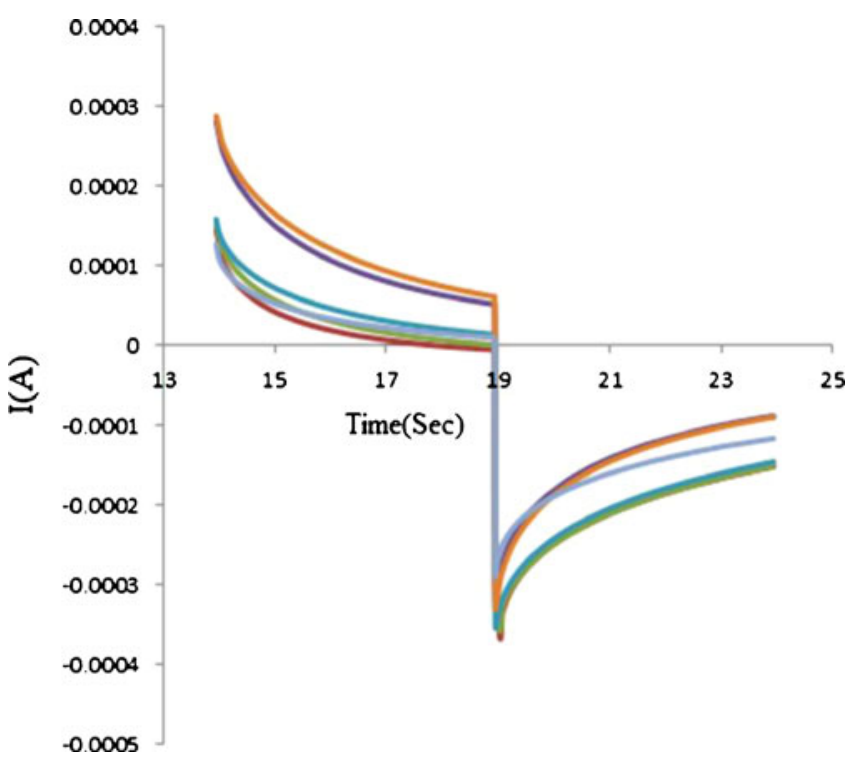

Figure 6. Chronoamperometric responses of biosensor in phosphate buffer $(\mathrm{pH} 7)$ and applied potential of about $0.01 \mathrm{~V}$, in the range $10^{-9}$ to $10^{-4} \mathrm{M}$ of acetaminophen. response current was observed at $\mathrm{pH}$ 7. In order to obtain the maximum bioactivity and optimal sensitivity, phosphate buffer solution of $\mathrm{pH} 7$ was selected for our experiments.

\subsection{Influence of scan rate}

The effect of scan rate on the electrochemical response for acetaminophen was assessed by cyclic voltammetry which is shown in figure 9. The results reveal that a positive shift in the anodic peak potentials occurs which confirms the irreversibility of the process when the scan rate is increased. The linear relationship that exists between the oxidation peak current $\left(I_{\mathrm{pa}}\right)$ and the square root of the scan rate $\left(v^{1 / 2}\right)$, is indicative of the fact that the oxidation process is predominantly diffusion-controlled in the whole range of scan rates studied.

\subsection{Calibration curve}

The calibration curve for acetaminophen in $\mathrm{pH} 7$ phosphate buffer was characterized (figure 10). The relationship

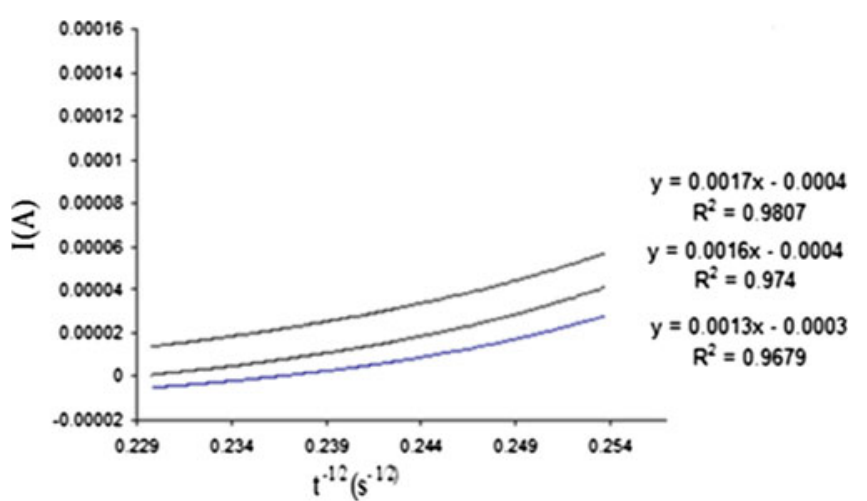

Figure 7. Plots of $I$ vs $t^{-1 / 2}$ obtained from $10^{-7}$ to $10^{-5} \mathrm{M}$ chronoamperograms in applied potential of about $0.01 \mathrm{~V}$.

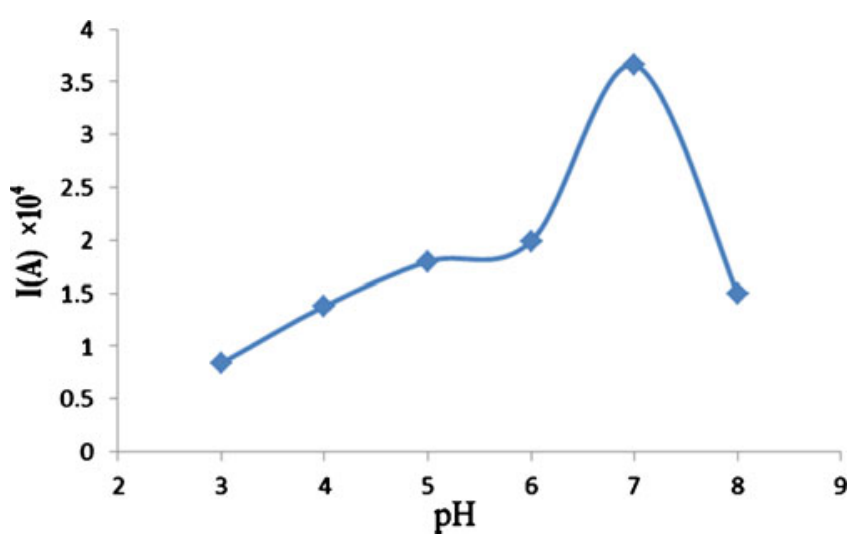

Figure 8. Effect of $\mathrm{pH}$ on peak currents of $10^{-5} \mathrm{M}$ acetaminophen in acetate buffer solution. 


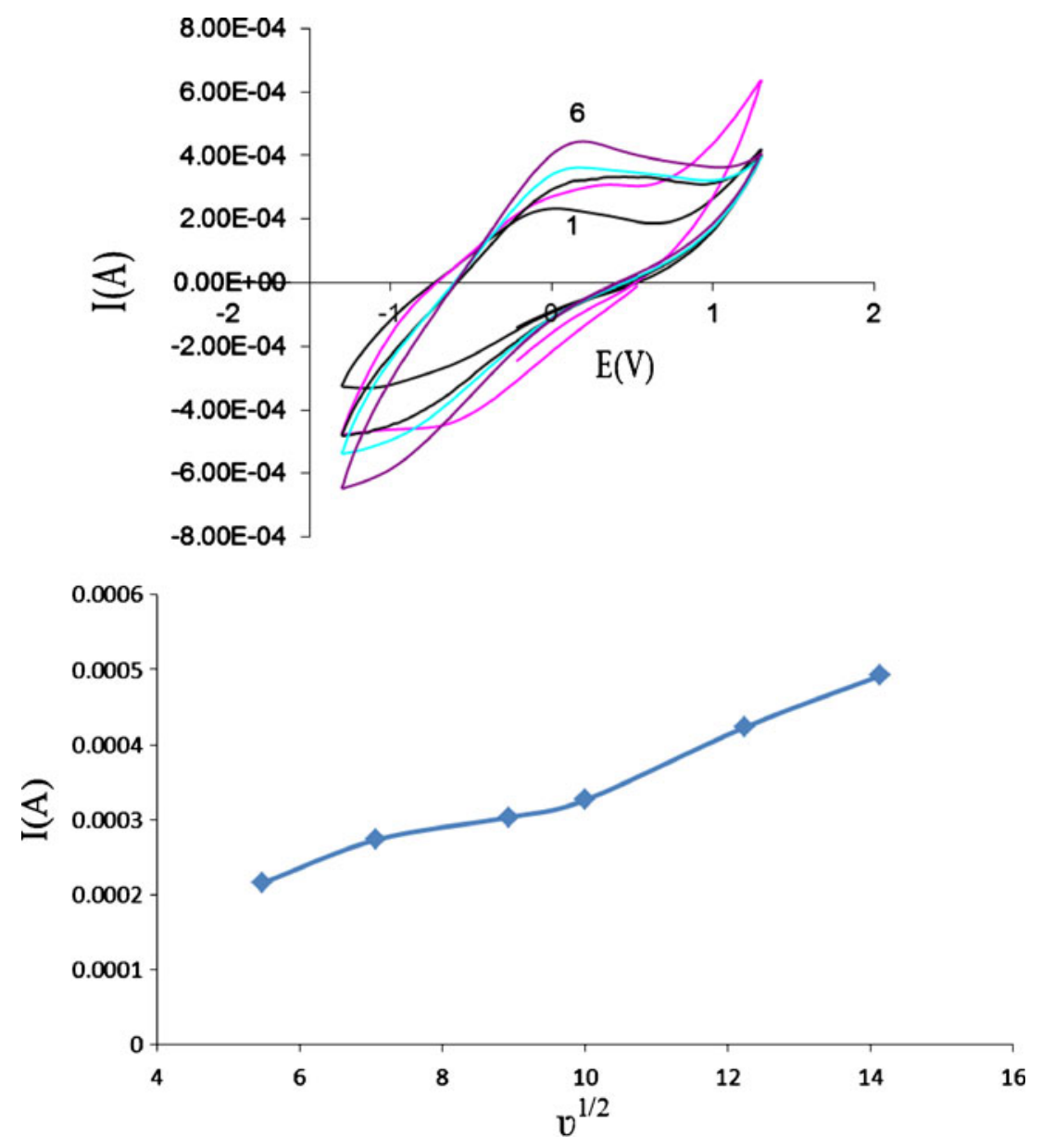

Figure 9. Peak currents of $10^{-5} \mathrm{M}$ acetaminophen at different scan rates.

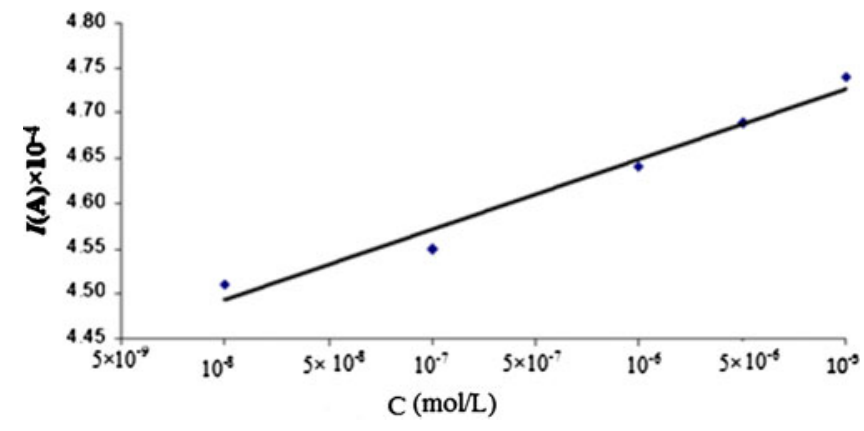

Figure 10. Calibration curve for acetaminophen.

between concentration and peak height anodic current was linear from $10^{-8}$ to $10^{-5} \mathrm{M}$ of acetaminophen.

\subsection{Determination of acetaminophen in human plasma}

The new developed biosensor was used for the determination of acetaminophen in human plasma and milk samples. The recovery of acetaminophen from human plasma and milk
Table 2. Acetaminophen analysis with PPy/banana graphite electrode in $\mathrm{pH} 7$.

\begin{tabular}{lcccc}
\hline Sample & Spiked(M) & Found(M) & Relative error & Recovery \\
\hline Milk & $5 \times 10^{-6}$ & $5.13 \times 10^{-6}$ & $6 \cdot 2$ & $103 \%$ \\
Plasma & $2 \times 10^{-6}$ & $1.82 \times 10^{-6}$ & -9 & $91 \%$ \\
\hline
\end{tabular}

samples was measured by spiking drug-free samples with a known amount of acetaminophen. For sample preparation, in each case, a few $\mathrm{ml}$ of methanol was added to sample, and then it was centrifuged and proteins were precipitated. After that the samples were diluted. The determination of ACT in pharmaceutical samples was carried out by the standard addition method in order to prevent any matrix effect. As can be seen from table 2, there is no interference from the plasma and milk samples. The performance characteristics of this new biosensor have been compared with the pervious works in table 3. As can be seen from this table, the limit of detection for the proposed biosensor, is much better than those reported in previous works and this new biosensor has a good linear range for the determination of acetaminophen. 
Table 3. Performance characteristics of some acetaminophen biosensors.

\begin{tabular}{|c|c|c|c|c|}
\hline Reference & $\begin{array}{l}\text { Electrochemical } \\
\text { technique }\end{array}$ & $\begin{array}{l}\text { Electrode type } \\
\text { (modifier) }\end{array}$ & $\begin{array}{l}\text { Limit of } \\
\text { detection }\end{array}$ & $\begin{array}{l}\text { Range of } \\
\text { calibration curve }\end{array}$ \\
\hline (Sun and Zhang 2007) & Chronoamperometry & MWCNT-film coated electrode & $2.4 \mu \mathrm{M}$ & $5-100 \mu \mathrm{M}$ \\
\hline (Fanjul-Bolado et al 2009) & Amperometry & Cobalt hydroxyl nanoparticles & $1.83 \mu \mathrm{M}$ & - \\
\hline (Silva et al 2006) & Cyclic voltammetry & Nafion coated tubular electrode & $17 \mu \mathrm{M}$ & - \\
\hline (Cao et al 2009) & Square wave voltammetry & Boron-doped diamond electrode & $0.49 \mu \mathrm{M}$ & $0 \cdot 5-83 \mu \mathrm{M}$ \\
\hline (Guan et al 2008) & Differential pulse voltammetry & Carbon ionic liquid electrode & $0 \cdot 3 \mu \mathrm{M}$ & $1 \mu \mathrm{M}-2 \mathrm{mM}$ \\
\hline (Kumar et al 2008) & Cyclic voltammetry & Nano- $\mathrm{TiO}_{2} /$ polymer coated & $2 \mu \mathrm{M}$ & $12-120 \mu \mathrm{M}$ \\
\hline (Ghorbani-Bidkorbeh et al 2010) & Differential pulse voltammetry & $\begin{array}{l}\text { Carbon nanoparticles modified } \\
\text { glassy carbon electrode }\end{array}$ & $0.05 \mu \mathrm{M}$ & $\begin{array}{l}0 \cdot 1-10 \mu \mathrm{M} \\
10-100 \mu \mathrm{M}\end{array}$ \\
\hline (Sima et al 2008) & Amperometry & $\begin{array}{l}\text { Gold nanoparticle modified } \\
\text { carbon paste electrode }\end{array}$ & $330 \mathrm{nM}$ & $6 \cdot 6-530 \mu \mathrm{M}$ \\
\hline (Xu et al 2009) & Amperometry & Carbon-coated nickel nanoparticles & - & $7 \cdot 8-110 \mu \mathrm{M}$ \\
\hline $\begin{array}{l}\text { Present } \\
\text { work }\end{array}$ & $\begin{array}{l}\text { Differential pulse } \\
\text { voltammetry }\end{array}$ & $\begin{array}{l}\text { Banana tissue/polypyrrole } \\
\text { carbon electrode }\end{array}$ & $0.01 \mu \mathrm{M}$ & $0.01-1 \mu \mathrm{M}$ \\
\hline
\end{tabular}

\section{Conclusions}

It has been demonstrated that the newly developed plant based bioelectrode, makes a reliable sensor for the detection of acetaminophen. The newly developed biosensor had a strong electrocatalytic effect on the oxidation of acetaminophen. According to the results, the newly developed biosensor had a strong electrocatalytic effect on the oxidation of acetaminophen with the overpotential being decreased by about $0.01 \mathrm{~V}$ as compared to the process at a bare graphite electrode $(0 \cdot 390 \mathrm{~V})$. The diffusion coefficient of $8.31 \times 10^{-6} \mathrm{~cm}^{2} \mathrm{~s}^{-1}$ for acetaminophen was also obtained using chronoamperometric study. The effects of $\mathrm{pH}$ and scan rate on the determination of acetaminophen was also studied. The proposed biosensor was successfully applied to determination of acetaminophen in biologic fluids.

\section{References}

Akyilmaz E and Dinckaya E 2000 Talanta 53505

Bard A J and Faulkner L R 1980 Electrochemical methods, fundamentals and applications (New York: John Wiley)

Botre F, Mazzei F, Lanzi M, Lorenti G and Botre C 1991 Anal. Chim. Acta 25559

Cao B C L, Medeiros R A, Rocha-Filho R C and Mazo L H 2009 Talanta 78748

Cosnier S 1999 Biosens. Bioelectron. 14443

Dunkerley S and Adams M J 1997 Lab. Autom. Inf. Manage. 33107

Erk N, Özkan Y, Banoğlu E, Özkan S A and Şentürk Z 2001 J. Pharm. Biomed. Anal. 24469

Eustaquio A, Blanco M, Jee R D and Moffat A C 1999 Anal. Chim. Acta $\mathbf{3 8 3} 283$

Fanjul-Bolado P, Lamas-Ardisana P J, Hernandez-Santos D and Costa-Garcia A 2009 Anal. Chim. Acta 638133

Felix F S, Yamashita M and Angnes L 2006 Biosens. Bioelectron. 212283

Genies E M, Bidan G and Diaz A F 1983 J. Electroanal. Chem. 149 101

Gerard M, Chaubey A and Malhotra B D 2002 Biosens. Bioelectron. 17345
Ghorbani-Bidkorbeh F, Shahrokhian S, Mohammadi A and Dinarvand R 2010 Electrochim. Acta $\mathbf{5 5} 2752$

Guan X S, Zhang H and Zheng J 2008 Anal. Bioanal. Chem. 391 1049

Ivaska A 1991 Electroanalysis 3247

Khomenko V G, Barsukov V Z and Katashinskii A S 2005 Electrochim. Acta $\mathbf{5 0} 1675$

Kumar K G and Letha R 1997 J. Pharm. Biomed. Anal. 151725

Kumar S A, Tang C F and Chen S M 2008 Talanta 76997

Li Y F 1997 Electrochim. Acta 42203

Lima A W O, Nascimento V B, Pedrotti J J and Angnes L 1997 Anal. Chim. Acta 354325

Liawruangrath S, Oungpipat W, Watanesk S, Liawruangrath B, Dongduen C and Purachat P 2001 Anal. Chim. Acta 44837

Majidi M R, Jouyban A and Asadpour-Zeynali K 2006 J. Electroanal. Chem. $\mathbf{5 8 9} 32$

Oungpipat W and Alexander P W 1994 Anal. Chim. Acta 29537

Pérez J L and Bello M A 1999 Talanta 481199

Ramanavicius A, Malinauskas A and Ramanaviciene A 2004 in: (ed.) D W Thomas, Advanced biomaterials for medical applications (Netherlands: Kluwer Academic Publishers)

Raoof J B, Ojani R and Rashid-Nadimi S 2004 Electrochim. Acta 49271

Rodenas V, García M S, Sánchez-Pedreño C and Albero M I 2000 Talanta $\mathbf{5 2} 517$

Silva M L S, Carcia M B Q, Lima J L F C and Barrado E 2006 Anal. Chim. Acta 573-574 383

Sima V, Cristea C, Lapadus F, Marian I O, Marian A and Sandulescu R 2008 J. Pharm. Biomed. Anal. 481195

Speed D J, Dickson S J, Cairns E R and Kim N D 2001 J. Anal. Toxicol. 25198

Sun D and Zhang H 2007 Microchim. Acta 158131

Tian F M, Zhu L D, Xu B and Zhu G Y 2001 Chin. Chem. Lett. 12 1011

Vidal J C, Garcia E and Castillo J R 1999 Sens. Actuators B57 219

Vilchez J L, Blanc R, Avidad R and Navalón A 1995 J. Pharm. Biomed. Anal. 131119

Wang Y 1999 Chin. J. Chromatogr. 17268

Wang J and Lin M S 1988 Anal. Chem. 601545

Xiong H, Xu H, Wang L and Wang S 2009 Microchim. Acta 167 129

Xu Z, Yue Q, Zhuang Z and Xiao D 2009 Microchim. Acta 164387

Yang B Y, Mo J Y and Yang X Y 1999 Chin. J. Chromatogr. 17477 